\title{
Research on University Students' Innovation and Entrepreneurship Competition
}

\author{
Yumian Liu and Shang Peng \\ Hunan Architecture Senior Technician School, Hunan Changsha, China \\ IBS School of Hunan University, Hunan Changsha, China \\ 239492576@qq.com,1397526193@qq.com
}

Keywords: College students; Innovation and entrepreneurship; Competition; Thinking; Education

\begin{abstract}
With the continuous improvement of urban construction, the relevant scientific educational model are constantly renewing and constructing, the concept of College Students' innovation and entrepreneurship is gradually advancing in higher education. In the realistic mode of university education, student's innovation and entrepreneurship competition is a form of university activities; the cultivation of innovative and entrepreneurial ideas in universities has effectively promoted the cultivation of middle school students' entrepreneurial technology. the education sector in the various cities, often organized the relevant university student's innovation and Entrepreneurship Competition Project, this type of game is effectively carried out, for the relevant university students employment to launch a new road, college students should carry out phase on innovation and entrepreneurship in the daily study and life, effectively implement, timely explore the popularity, full process, full range and full social trends to construct innovation and entrepreneurship training system construction. This paper analyzes and discusses the thinking and exploration of College Students' innovation and entrepreneurship competition.
\end{abstract}

\section{Introduction}

With the country's continuous improvement and innovation in the education system, the requirements for the innovation and Entrepreneurship of college students are also in the gradual reform. According to the development of education in recent years, in 2015, the Ministry of education in conjunction with the national development and Reform Commission, Ministry of industry, Ministry of human resources and social, the Central Committee of the Communist Youth League of China and Jilin Province People's Government jointly organized the first Chinese college students' innovation and entrepreneurship competition. The student's innovation and Entrepreneurship Competition with the various national leadership attention, on the eve of the finals, Premier Li Keqiang gave the important instructions of" take the innovation and entrepreneurship education into the personnel training, Vigorously develop public entrepreneurship, innovation,". in all aspects of feedback. All shows that the university students' innovation and entrepreneurship competition has the significance of the times, and in the future development, also has a very powerful driving force.

\section{The Highlights of Innovation and Entrepreneurship Competition for College Students}

In the process of the creation and innovation of college students, according to purpose and requirement of the competition, important force in the competition should be to carry out the training program on the implementation of amendments, to improve the curriculum system of college students, and effectively improve the teaching mode of University, strengthen the practice of innovation and entrepreneurship related to college students and a series of goals. The goal with effective implementation can improve the state of the university personnel training number, enhance the quality standard of talent, among them, the key is greatly cultivate the spirit of innovation, innovation consciousness and innovation and entrepreneurship ability. Students' 
innovation and entrepreneurship competition has gradually attracted the attention of relevant scholars at home and abroad.

In the innovation and entrepreneurship competition in college students, there are a few highlights, the following analysis of the advantages of competition:

College Students' Innovation and Entrepreneurship Competition Is with Long Time and Large Scale. In the process of the national college student's innovation and entrepreneurship competition, the experience of the time set up a long, long time competition ensure that students can effectively guarantee the amount of free time. This large-scale national competition, effectively enhance and promote the student's determination and strength to join in the innovation and entrepreneurship activities, and enhance the status of the scale of activities.

Students' Innovation and Entrepreneurship Competition Works Are in High Quality. In the college students' innovation and entrepreneurship competition during the course of the game, the gold content of the students' work is relatively high, out of the empty talk status, to ensure the real technical content display for college students.

Investment Value in College Students' Innovation and Entrepreneurship Competition Projects Is Large. In the college students' innovation and entrepreneurship competition, because the game directly follow the real market demand and related market conditions to show the effective, in view of this situation, in the course of innovation and entrepreneurship competition, the relevant enterprises have also carried out a relatively large capital investment, in order to be able to introduce new talents for their own enterprises to promote power.

The Portent of Innovation and Entrepreneurship Competition Is Rich. In the process of college students' innovation and entrepreneurship competition, during the finals of the competition, colleges and universities associated the innovation and entrepreneurship students to carry on the detailed discussion and research, put the theme of innovation and entrepreneurship competition for college students in the rich contents of College Students' innovation points. Really take innovation and entrepreneurship competition of college students as the promoted force of innovation and entrepreneurship education in Colleges and universities and effective develop College Students' mass innovation, culture innovation concept.

The Follow-up Work of the University Students' Innovation and Entrepreneurship Competition Is Closed. After the end of the game in the university student innovation and entrepreneurship competition, the follow-up of the university student's innovation and entrepreneurship consulting and related employment guidance center is in accordance with the concept of college student's innovation and Entrepreneurship to union College student's venture capital institutions. Such organizations effectively enhance the opportunity to enhance the students' innovation and entrepreneurship and related knowledge learning.

\section{Scan on the Current Situation of College Students' Innovation and Entrepreneurship Competition}

According to the current situation of College Students' innovation and entrepreneurship competition, we can find the following problems:

The Type and the Level of Colleges and Universities to Participate in University Students' Innovation and Entrepreneurship Competition, Is not Balanced. From the perspective of college type, public universities accounted for $96 \%$ of the finalists, private accounting for 4\%; "211 Project" and "985 Project" accounted for 57\%, more than half of the total number of entries into the finals; From the point of view of the university level, undergraduate account for $97 \%$, only $3 \%$ of the Higher Vocational College. From the above data, we can see that in the propaganda of University College Students' innovation and entrepreneurship, there are still many imperfect conditions. Many schools didn't show students effective process and advantages of student's innovation and entrepreneurship competition students.

The University Students' Innovation and Entrepreneurship Competition Is not evenly distributed in the Participating Universities. Form the distribution of the participants in the 
college students' innovation and entrepreneurship competition; we can see that the relevant personnel distribution is very uneven, this situation directly led to the loss of related personnel.

The Proportion of the Original Project of Innovation and Entrepreneurship Competition of University Students is not high. In the course of the competition of College Students' innovation and entrepreneurship, related project will appear a lack of originality. The main cause of this situation is that the higher education schools are not comprehensive enough to cultivate the students' innovation ability.

The Competition Form of University Students' Innovation and Entrepreneurship Competition Is too concentrated. In the college students' innovation and entrepreneurship competition it is not difficult to find that related projects have certain of the format. this problem is mainly due to the University's own school type and school focusing on the professional, resulting in the process of in college students' innovative and Entrepreneurship competition, events are relatively concentrated, projects related to the coverage is narrow.

\section{Thoughts on the Current Situation of College Students' Innovation and Entrepreneurship Competition}

In view of the current situation of College Students' innovation and entrepreneurship competition, it can be divided into the following aspects to solve the problem:

The Concept Transformation of Innovation and Entrepreneurship Education in College Students' Innovation and Entrepreneurship. The direct influence of the innovative thinking concept is the power and trend of the future development of the society and the transformation of this kind of thinking can effectively guarantee the effective reform and promotion of the society. The transformation of College Students' innovative and entrepreneurial ideas can bring about an unprecedented challenge and opportunity to the related university education,

Therefore, the change of College Students' innovation and entrepreneurship is a process of improving the educational concept. In the existing situation of college education, college students' innovation thinking of effective improvement and updating is the key problem. This problem in the improvement process should focus on people-oriented ideological construction in the process of education of college students. The construction of this way of thinking, can effectively ensure that students in the school life and learning, the reasonable and effective combination professional knowledge and innovation ability.

\section{In the Process of College Students' Innovation and Entrepreneurship, Should Pay Attention to the Cultivation of Talents}

In the process of higher education, the cultivation of talents is one of the most concerned points of education work. Innovation and entrepreneurship education should also be transferred to the relevant concept of training talents in the first place, and the correction of this position can effectively improve and improve the current higher education mode, and further improve the ideological construction of College Students' innovative and entrepreneurial ideas. With the continuous extension of time, the relevant education departments have gradually make innovative spirit, entrepreneurial awareness and related innovation and entrepreneurship ability as important indicators of the measure to evaluate the evaluation of college students comprehensive personnel training. In the teaching quality and the employment quality requirements of higher education, should have a clear measure of system construction. Only such standard construction requirements, can we effectively enhance related innovative consciousness and innovative spirit and innovation ability of the comprehensive situation, laid a good foundation for the future high standard talents cultivating. 


\section{Research on the Countermeasures of College Students' innovation and Entrepreneurship Competition}

According to the situation of the university students' innovation and entrepreneurship competition, can carry out to analyze from following several points.

Comprehensively popularize the concept of innovation and Entrepreneurship of College Students in the education concept of the existing higher education, the lack of the concept training of the innovation and Entrepreneurship of college students, the lack of this knowledge, to a great extent hindered the development of College Students' innovation and entrepreneurship. Now the State Education Department should be in all grades of the school and all the students to carry out innovation and entrepreneurship education. The form of this kind of education can effectively enhance the attention of students in the campus to the concept of innovation and entrepreneurship,

Can also be effective in the school to Public the related college student's innovation and entrepreneurship competition knowledge, making the school's students have gradually accepted the innovation and entrepreneurship education, establish the spirit of innovation and entrepreneurship.

The Improvement of the Whole Process of College Students' Innovation and Entrepreneurship. Analysis and Research on the employment situation of college students now, with the continuous advance of social progress and gradually reduce of related business personnel number; this phenomenon should arouse the attention of major colleges and universities. In view of this kind of question, the universities should merge the education of innovation and entrepreneurship into the road of the related personnel training effectively, comprehensively to enhance the survival efficiency of college student's innovation and entrepreneurship. In throughout of the school's innovation and entrepreneurial knowledge, should inculcate knowledge to students staring from entering the school, until after graduation to improve college students' entrepreneurial path.

Overall the Guidance of College Students' Innovation and Entrepreneurship. In the process of College Students' innovation and entrepreneurship, except to improving the construction of the school's own learning system, should also be in the external environment to create an effective environment, and be initiative to look for the outside source environment, strengthening to get cooperate opportunities of university campus and the relevant enterprises. On the campus of the University, to construct innovative entrepreneurship education, practice, simulation, display and the construction of other venues, making the curriculum education of the innovation and Entrepreneurship effective integrated into all corners of the University campus. Cultivate College Students' innovation and entrepreneurship with the unity of internal and external in the University campus, so that it ensures that everything is a training ground for the education of creation and innovation and entrepreneurship innovation classroom.

The Construction for all of College Students' innovation and Entrepreneurship. In the process of College Students' innovation and entrepreneurship, in view of the related study and the practice request, it no longer is the simple for university school to arranges several enterprise teachers to carry on the simple teaching, instead, college students should be put in the position of the top priority of training talents, this result should be a comprehensive system to participate in the project by the school's individual personnel. in the whole process of the realization of College students innovation and entrepreneurship, should be in the university campus, actively introduce the relevant management system, implement the management system, and actively cooperate with the relevant business teacher planning, to realize the cultivation of students' innovation and entrepreneurship in school life and learning state, to achieve the goal for all.

\section{Summary}

With the continuous development of the country, the relevant innovative ideas continue to advance; such a social atmosphere for college students in the future business development prospects raised a new request. The development of university students' innovation and entrepreneurship competition can help students to carry out the practice of innovative and entrepreneurial knowledge and can also 
effectively promote the construction and improvement of College Students' innovative and entrepreneurial ideas. College students during the learning, should establish the innovative entrepreneurial ideas, only the establishment of this thought, in the future of social development, will entrepreneurial road is more stable. There are still a lot of problems in the innovation and entrepreneurship competition for college students, improvements in these areas, should be carried out by the professional personnel for a long time to explore, Only in this way can we effectively guarantee the proper settlement of relevant issues, Coupled with the actual situation of the relevant innovation and entrepreneurship competition to conduct an effective combination of further innovation and entrepreneurship competition will be held to promote a new level of full display

\section{References}

[1] Liu Xiaofu.Thinking and exploration on Internet plus" college students innovation and entrepreneurship competition [J].Journal of Guangdong Communication Polytechnic, 2015,04: 121-124.

[2] Zhang Kejing. Study on the entrepreneurial learning of college students based on the perspective of knowledge acquisition [D].Donghua University, 2014.

[3] Cao Yang. Research on innovation and entrepreneurship education in universities and Colleges under the background of transformation of economic development mode [D].Northeast Normal University, 2014.

[4] Zhang Shengli, Hu Xirui.Reflections on the mechanism of university students' innovation and entrepreneurship education in Colleges and universities [J].Herald (on a), and 2016,02:162-163.

[5] Wang Weizhou. Study on the ways of cultivating entrepreneurial ability of college students majoring in economics and management [D]. Shanxi University of Finance and Economics, 2013.

[6] Zhu Guangjiao. Analyze of the training strategies of College Students' self-entrepreneurship ability [D]. China University of Geosciences (Beijing), 2010.

[7] Li Huifeng. Research on the entrepreneurship education of college students in China [D]. Lanzhou University, 2010.

[8] Zhu Ruifeng. Analysis of the government function in the development of innovation and Entrepreneurship of university students [D]. South China University of Technology, 2015.

[9] Yu Ruiling. An Empirical Study on the entrepreneurship education of college students in China [D]. Xiamen University, 2006.

[10] Song ZhiShuai, Nan Guojun. On the cultivation of the founder of the newly established enterprises and the innovation of the mode of University Entrepreneurship Education-- a case study of "six in one" collaborative innovation model [A].China Soft Science Research Association. The Tenth Annual Conference of China Soft Science Conference [C].China Soft Science Research Association: 2015:7. 